\title{
ЕМПІРИЧНЕ ДОСЛІДЖЕННЯ ОСОБЛИВОСТЕЙ ГРОМАДЯНСЬКОЇ ТА НАЦІОНЛЬНОЇ САМОІДЕНТИФІКЦІЇ МОЛОДІ: БАЗОВІ ПОНЯТТЯ І ПОКАЗНИКИ
}

У річищі конструктивно-дискурсивного підходу самоідентифікацію розглянуто як гнучкий дискурсивний конструкт, що постійно трансформується в процесі соціальної взаємодії і зміни психосоціального досвіду особи. 3 огляду на роль комунікації в розвитку ідентифікаційних процесів запропоновано класифікацію самоідентифікацій на основі способу знаково-символьної взаємодії особи з іншими та світом. Виокремлено чотири рівні самоідентифікації, кожному з яких відповідає певний спосіб використання знаку як засобу: а) позначення ідентичності, б) символічного іiі осмислення, в) конструювання категорій та ідеалів, з якими особа себе ідентифікує, г) конструювання умов і правил перетворення реальності. Операціоналізовано базові поняття: національну самоідентифікацію визначено як усвідомлення належності до політичної нації - соціокультурної спільноти, що має свій досвід державності, традиції, міфи і символіку, спільні цінності й очікування щодо майбутнього; громадянську - як самовизначення особистості в континуумі виявів суб'єктності та ототожнення із спільнотою, члени якої готові і здатні до обстоювання своїх інтересів у відповідальній, конструктивній соціальній взаємодії. Таким чином розмежовано ці поняття, визначено показники громадянської і національної самоідентифікації та висунуто припущення про особливості їх виявів на різних рівнях.

Ключові слова: громадянська та національна самоідентифікація, комунікативні практики, спосіб використання знаку.

Проблема. Успішність соціальних змін, яких потребує українське суспільство, значною мірою визначається ідентифікаційними процесами, зумовленими психологічними та соціокультурними чинниками. Так, наприклад, розвиток громадянського суспільства, детермінований особливостями громадянської ідентифікації, неможливий без змін у дистанціюванні влади, у ставленні до невизначеності майбутнього, без інтегрування людей у громадські об'єднання, без регуляції афективності, атрибуції, без фокусування на сучасному i майбутньому - тобто тих параметрів культури, які визначають вектор суспільного розвитку і самі перспективи розвитку (Г. Гофстеде, К. Клакхон, Т. Парсонс, Е. Шилз та ін.). Ситуація ускладнюється мінливістю і динамічністю світових процесів, які зумовлюють “дроблення” національної самоідентифікації i конструювання водночас наднаціональної, транснаціональної, субнаціональної ідентичностей, 
що гальмує творення політичної нації і створює загрози для успішного існування й розвитку держави. Тому формується запит на визначення чинників та ресурсів активізації процесів громадянської і національної самоідентифікації.

Ключовим поняттям у дослідженнях ідентифікації є комунікація - як засіб трансляції власних смислів [1] і як середовище, у якому особистість самовизначається, співвідносить, порівнює і переживає свою тотожність комунікативному образу “Я", тобто досягає ідентичності [2]. У такому разі комунікативні процеси можна розглядати як такі, що породжують ідентичності, а комунікативні практики та їх трансформації - як, відповідно, чинник і ресурс розвитку національної та громадянської самоідентифікації.

На першому етапі дослідження зумовленості самоідентифікаційних процесів трансформаціями комунікативних практик постала проблема визначення базових категорій і показників. Узагальнення даних наукових розвідок з проблем громадянської та національної ідентичностей дає підстави констатувати, що в сучасних політикопсихологічних концепціях уявлення про сутнісні відмінності, показники та індикатори громадянської і національної самоідентифікації схематичні і різнопланові, дефініції “перетинаються", а то й взагалі не дають змоги розрізняти базові поняття. Така розмаїтість змістових i структурних інтерпретацій досліджуваних феноменів суттєво ускладнює конструювання теоретичної моделі емпіричного дослідження, а тому постає завдання визначення змістових і динамічних особливостей та показників громадянської і національної самоідентифікацій, окреслення простору їх функціонування та взаємозумовленості.

Методологічною основою дослідження обрано конструктивнодискурсивний підхід, відповідно до якого:

- дискурс розглядається як інструмент і результат конструювання ідентичностей;

- констатується взаємозумовленість дискурсу і комунікативних практик;

- наголошується на ситуативності ідентифікаційного дискурсу (послідовній, інституціональній і риторичній);

- самоідентифікація особистості постає як гнучкий дискурсивний конструкт, що постійно трансформується в просторі соціальної взаємодії;

- визнається принципова можливість і неперервність конструювання компонентів ідентичностей, а водночас і впливу на процеси самоідентифікації.

Відтак процес самоідентифікації постає як динамічний, нелінійний і значною мірою зумовлений особливостями знаково-символьної комунікації особи на різних рівнях соціальної взаємодії. 
3 огляду на кінцеву мету дослідження (визначення особливостей впливу комунікативних практик на громадянську і національну самоідентифікацію молоді) та 3 урахуванням концептуальних засад конструктивно-дискурсивного підходу логіка конструювання робочих дефініцій та відбору емпіричних показників передбачала зосередження на тих самоідентифікаційних конструктах, які мають вищий імовірнісний потенціал змін унаслідок трансформування комунікативних практик.

Пошук комунікативних координат, у яких можна було б вибудувати теоретичну модель дослідження, привів нас до підходу, застосованого В. О. Колотаєвим i О. В. Улибіною для обгрунтування стадіальної моделі ідентичності [3]. Запозичивши ідею цих дослідників, які спосіб використання знаку поклали в основу класифікації ідентифікаційних процесів, ми виділили чотири рівні самоідентифікації, на кожному з яких знак використовується як засіб: 1) позначення ідентичності, 2) символічного іiі осмислення, 3) конструювання категорій та ідеалів, з якими особа себе ідентифікує, 4) конструювання умов і правил перетворення реальності. У термінології R. Jenkins перший рівень відповідає номінальній ідентичності, а три наступні є різновидами віртуальної ідентичності і характеризують їі змісти [4]. Зміни в номінальній ідентичності зумовлюють зміни віртуальної, можлива і зворотна зумовленість [5] .

На першому рівні (рівень знакової репрезентації) комунікація і осмислення світу здійснюються за допомогою знаків, що мають індексальну природу (знаки-прикмети за Пірсоном). Самоідентифікування відбувається в ситуації виконання формальних процедур (заповнення анкети, відповіді на запитання тощо). Громадянство і належність до нації сприймаються як природне явище (даність), а відтак не рефлексуються, не викликають запитань, сумнівів, критики, не оцінюються.

На другому рівні (рівень інтерпретації смислів) комунікація здійснюється за допомогою знаків-символів. Реальність і символ в уявленнях суб' єкта нерозривно пов'язані, за межами символу реальності не існує. Самоідентифікація цілком визначається дискурсом, суб'єкт засвоює і транслює ідеї, які сприймаються як абсолютно істинні і єдино правильні. Громадянська і національна ідентичності розглядаються як реальність, що потребує від людини повної відповідності встановленим правилам і вимогам (“справжній громадянин - це... ”, “бути українцем означає...”). Модель комунікації і конструювання дискурсу ідентичності спирається на норми і настанови, отримані з авторитетного джерела.

На третьому рівні (рівень конструювання смислів) метою комунікації $є$ пошук смислів, при цьому знаки використовуються для 
конструювання соціальних категорій, узагальнень та формування реальності, яка відповідає ідеалу. Відбувається самоідентифікація з образом ідеального майбутнього (уявлення про ідеальну громадянську спільноту, державу). Реальність, яка не відповідає бажаному, дратує i не приймається. Є розуміння того, що громадянська і національна ідентичності можуть виявлятися по-різному, однак власний варіант видається об'єктивнішим (правильнішим). Суб'єкт намагається дотримуватися правил і підкоряється їм, хоч вони й далекі від ідеалу. Це модель поведінки суб'єкта, який критично осмислює знання і формує власне бачення ситуації.

На четвертому рівні (рівень конструювання умов і правил перетворення реальності) у процесі комунікації конструюються умови існування знакового середовища, правила й умови для створення правил, які змінюють ситуацію і роблять їі прийнятною. Відбувається ідентифікація себе як суб'єкта, орієнтованого на взаємодію 3 метою перетворення реальності відповідно до власних уявлень, створення умов і правил життя. Спостерігається відмова від ототожнення 3 масовими цінностями та ідеалом, усвідомлення їх ілюзорності, розуміння відносності і ситуативності ідентифікацій, орієнтація на самостійне прийняття рішення щодо того, як діяти в певній ситуації.

За такого підходу стають зрозумілими труднощі з дефініціями, адже, як свідчать результати наших попередніх досліджень, на рівні знакових репрезентацій, а в окремих випадках і на рівні репрезентацій смислів вирізнити специфіку громадянської і національної самоідентифікацій не видається можливим, насамперед через “бідність” репрезентацій громадянського і національно-державного.

На основі запропонованої теоретичної моделі самоідентифікацій було сформульовано робоче визначення поняття "громадянська самоідентифікація” та виокремлено емпіричні показники, за якими можна оцінити ії особливості на кожному з рівнів.

Громадянську самоідентифікацію визначено як усвідомлення особистістю своєї належності до спільноти, члени якої готові і здатні до обстоювання своїх інтересів у відповідальній, конструктивній соціальній взаємодії. Громадянська самоідентифікація має процесуальний характер і на різних рівнях взаємодії постає як: а) усвідомлення власної спроможності обстоювати свої громадянські права та цінності; б) усвідомлення значущості дотримання прав інших і солідаризація 3 іншим або групою, члени якої обстоюють певні громадянські цінності, практики та моделі поведінки; в) конструювання бажаної реальності через вплив на прийняття рішень політичною владою та державними інститутами.

За результатами аналізу досліджень з проблеми громадянської ідентифікації було виокремлено низку показників і висунуто припу- 
щення про особливості їх виявів на різних рівнях громадянської самоідентифікації (табл.).

Таблиия

\begin{tabular}{|c|c|c|c|c|}
\hline \multicolumn{5}{|c|}{ Показники громадянської самоідентифікації } \\
\hline \multirow[b]{2}{*}{ Показники } & \multicolumn{4}{|c|}{ Особливості виявів на різних рівнях самоідентифікації } \\
\hline & $\begin{array}{c}\text { рівень зна- } \\
\text { кової репре- } \\
\text { зентації }\end{array}$ & $\begin{array}{c}\text { рівень інтерп- } \\
\text { ретації смис- } \\
\text { лів } \\
\end{array}$ & $\begin{array}{c}\text { рівень конст- } \\
\text { руювання } \\
\text { смислів }\end{array}$ & $\begin{array}{c}\text { рівень конст- } \\
\text { руювання } \\
\text { умов і правил }\end{array}$ \\
\hline $\begin{array}{l}\text { 1. Суб’єктна } \\
\text { самоідентифі- } \\
\text { кація }\end{array}$ & $\begin{array}{l}\text { не арти- } \\
\text { кулюється; } \\
\text { зовнішня } \\
\text { детерміна- } \\
\text { ція актив- } \\
\text { ності; } \\
\text { ставленнє- } \\
\text { вий компо- } \\
\text { нент } \\
\text { не сформо- } \\
\text { ваний; цілі } \\
\text { і цінності } \\
\text { активності } \\
\text { не рефлек- } \\
\text { туються і } \\
\text { не визна- } \\
\text { чаються } \\
\text { самостійно }\end{array}$ & $\begin{array}{l}\text { артикульова- } \\
\text { на, частково } \\
\text { відрефлексо- } \\
\text { вана; } \\
\text { переважання } \\
\text { зовнішньої } \\
\text { детермінації; } \\
\text { активність } \\
\text { регулюється } \\
\text { засвоєними } \\
\text { нормами і } \\
\text { правилами; } \\
\text { ставлення } \\
\text { формуються } \\
\text { дискурсом, } \\
\text { не аналізу- } \\
\text { ються; “я } \\
\text { хочу” відпо- } \\
\text { відати очіку- } \\
\text { ванням } \\
\text { громади }\end{array}$ & $\begin{array}{l}\text { інтенціона- } \\
\text { льна; } \\
\text { внутрішня } \\
\text { детермінація } \\
\text { активності; } \\
\text { пропоновані } \\
\text { норми, мо- } \\
\text { тивації, цілі } \\
\text { і цінності } \\
\text { аналізують- } \\
\text { ся, інтерпре- } \\
\text { туються і } \\
\text { присвою- } \\
\text { ються вибір- } \\
\text { ково. } \\
\text { Довільне } \\
\text { визначення } \\
\text { цілей, сфер і } \\
\text { форм грома- } \\
\text { дянської } \\
\text { активності. } \\
\text { “Я здатен”, } \\
\text { “Я знаю”, } \\
\text { “Я досягаю”. }\end{array}$ & $\begin{array}{l}\text { Самопотен- } \\
\text { цію-вання, } \\
\text { конструю- } \\
\text { вання образу } \\
\text { бажаного } \\
\text { тут і тепер, } \\
\text { вибір спосо- } \\
\text { бів дії; } \\
\text { "Я розвива- } \\
\text { юсь і реалі- } \\
\text { зую себе” }\end{array}$ \\
\hline $\begin{array}{l}\text { 2. Локус кон- } \\
\text { тролю соці- } \\
\text { альної відпо- } \\
\text { відальності }\end{array}$ & $\begin{array}{l}\text { екстерна- } \\
\text { льний }\end{array}$ & $\begin{array}{l}\text { переважає } \\
\text { екстерналь- } \\
\text { ний }\end{array}$ & $\begin{array}{l}\text { переважає } \\
\text { інтерналь- } \\
\text { ний }\end{array}$ & $\begin{array}{l}\text { інтерналь- } \\
\text { ний }\end{array}$ \\
\hline $\begin{array}{l}\text { 3. Потреба } \\
\text { у свободі }\end{array}$ & $\begin{array}{l}\text { низька, } \\
\text { переважно } \\
\text { свобода } \\
\text { "я" }\end{array}$ & $\begin{array}{l}\text { низька, гото- } \\
\text { вність до } \\
\text { самообме- } \\
\text { жень }\end{array}$ & $\begin{array}{l}\text { середній } \\
\text { рівень, ви- } \\
\text { знання права } \\
\text { іншого } \\
\text { на свободу }\end{array}$ & $\begin{array}{l}\text { високий } \\
\text { рівень (пот- } \\
\text { реба } \\
\text { у свободі } \\
\text { прийняття } \\
\text { рішень) }\end{array}$ \\
\hline $\begin{array}{l}\text { 4. Практики } \\
\text { громадянської } \\
\text { взаємодії }\end{array}$ & неузвичаєні & $\begin{array}{l}\text { приймаються } \\
\text { пропоновані } \\
\text { авторитетни- } \\
\text { ми іншими } \\
\text { без рефлексії }\end{array}$ & $\begin{array}{l}\text { приймають- } \\
\text { ся вибірко- } \\
\text { во, } \\
\text { після аналізу } \\
\text { доцільності } \\
\text { активності }\end{array}$ & $\begin{array}{l}\text { конструю- } \\
\text { ються під } \\
\text { конкретне } \\
\text { завдання } \\
\text { відповідно } \\
\text { до особли- } \\
\text { востей ситу- } \\
\text { ації } \\
\end{array}$ \\
\hline
\end{tabular}




\begin{tabular}{|c|c|c|c|c|}
\hline \multirow[b]{2}{*}{ Показники } & \multicolumn{4}{|c|}{ Особливості виявів на різних рівнях самоідентифікації } \\
\hline & $\begin{array}{c}\text { рівень зна- } \\
\text { кової репре- } \\
\text { зентації }\end{array}$ & $\begin{array}{c}\text { рівень інтерп- } \\
\text { ретації смис- } \\
\text { лів }\end{array}$ & $\begin{array}{c}\text { рівень конст- } \\
\text { руювання } \\
\text { смислів }\end{array}$ & $\begin{array}{c}\text { рівень конст- } \\
\text { руювання } \\
\text { умов і правил }\end{array}$ \\
\hline $\begin{array}{l}\text { 5. Можливі } \\
\text { “я” суб’єкта } \\
\text { громадянської } \\
\text { взаємодії та } \\
\text { стратегї̈ їх } \\
\text { досягнення }\end{array}$ & $\begin{array}{l}\text { переважан- } \\
\text { ня негатив- } \\
\text { них } \\
\text { можливих } \\
\text { "я" }\end{array}$ & $\begin{array}{l}\text { позитивні } \\
\text { символічні } \\
\text { можливі “Я”, } \\
\text { стратегій } \\
\text { немає }\end{array}$ & $\begin{array}{l}\text { позитивні } \\
\text { відрефлек- } \\
\text { совані мож- } \\
\text { ливі “я”, } \\
\text { стратегії } \\
\text { схематичні } \\
\end{array}$ & $\begin{array}{l}\text { позитивні } \\
\text { метафоричні } \\
\text { можливі } \\
\text { "Я”, є стра- } \\
\text { тегії їх дося- } \\
\text { гнення }\end{array}$ \\
\hline $\begin{array}{l}\text { 6. Моделі } \\
\text { громадянської } \\
\text { активності }\end{array}$ & ритуальні & $\begin{array}{l}\text { традиційні, } \\
\text { звичаєві }\end{array}$ & $\begin{array}{l}\text { регламенто- } \\
\text { вані законом }\end{array}$ & $\begin{array}{l}\text { конструю- } \\
\text { вання пра- } \\
\text { вил і впро- } \\
\text { вадження їх } \\
\text { у життя }\end{array}$ \\
\hline $\begin{array}{l}\text { 7. Часова орі- } \\
\text { єнтація }\end{array}$ & $\begin{array}{l}\text { коротко- } \\
\text { строко-ва } \\
\text { (“тут } \\
\text { i зараз”) }\end{array}$ & $\begin{array}{l}\text { короткостро- } \\
\text { кова, перева- } \\
\text { жає } \\
\text { спрямова- } \\
\text { ність } \\
\text { у минуле }\end{array}$ & $\begin{array}{l}\text { довгостро- } \\
\text { кова (спря- } \\
\text { мованість } \\
\text { у майбутнє) }\end{array}$ & $\begin{array}{l}\text { довгостро- } \\
\text { кова (істина } \\
\text { відносна, усе } \\
\text { може зміню- } \\
\text { ватись, го- } \\
\text { ловне - } \\
\text { досягнення } \\
\text { цілей) }\end{array}$ \\
\hline $\begin{array}{l}\text { 8. Дистан- } \\
\text { ційованість } \\
\text { влади }\end{array}$ & $\begin{array}{l}\text { відмежу- } \\
\text { вання (різні } \\
\text { світи) }\end{array}$ & $\begin{array}{l}\text { значна (влада } \\
\text {-даність, за- } \\
\text { конність зна- } \\
\text { чення не має) }\end{array}$ & $\begin{array}{l}\text { мала диста- } \\
\text { нція (влада } \\
\text { має спирати- } \\
\text { ся на закон } \\
\text { і відповідати } \\
\text { критеріям } \\
\text { добра і зла) }\end{array}$ & $\begin{array}{l}\text { дистанція } \\
\text { незначна } \\
\text { (влада - } \\
\text { інструмент } \\
\text { досягнення } \\
\text { цілей) }\end{array}$ \\
\hline $\begin{array}{l}\text { 9. Інтегрова- } \\
\text { ність у грома- } \\
\text { дянську } \\
\text { спільноту }\end{array}$ & мінімальна & $\begin{array}{l}\text { середня (очі- } \\
\text { кування захи- } \\
\text { сту } \\
\text { у відповідь } \\
\text { на відданість) }\end{array}$ & $\begin{array}{l}\text { висока (го- } \\
\text { товність } \\
\text { відповідати } \\
\text { за себе } \\
\text { і близьких) }\end{array}$ & $\begin{array}{l}\text { “Я”- } \\
\text { свідомість } \\
\text { (вирішити } \\
\text { завдання } \\
\text { важливіше, } \\
\text { ніж зберегти } \\
\text { взаємини) } \\
\end{array}$ \\
\hline $\begin{array}{l}\text { 10. Сенс (цілі) } \\
\text { громадянства }\end{array}$ & $\begin{array}{l}\text { невизна- } \\
\text { чені }\end{array}$ & $\begin{array}{l}\text { виконання } \\
\text { соціальної } \\
\text { ролі }\end{array}$ & $\begin{array}{l}\text { мрії про } \\
\text { майбутнє }\end{array}$ & $\begin{array}{l}\text { перетворе- } \\
\text { ння } \\
\text { реальності }\end{array}$ \\
\hline
\end{tabular}

Наиіональна самоідентифікаиія в межах даного дослідження визначається як усвідомлення особою свої належності до політичної нації - соціокультурної спільноти, що має свій досвід державності, традиції, міфи і символіку, спільні цінності та очікування щодо майбутнього.

Очевидно, що ступінь ірраціональності, емоційної навантаженості, політичної та ідеологічної ангажованості національної самоідентифікації значно вищий, ніж громадянської, а тому передбачити 
ймовірні конфігурації показників національної самоідентифікащії та особливості їх виявів на різних рівнях на етапі теоретичного аналізу не видається можливим.

Особливості національної самоідентифікації молоді передбачається визначати за результатами якісного і кількісного аналізу конструктів, що репрезентують:

- переживання, пов'язані з усвідомленням належності до української політичної нації (позитивні-негативні-амбівалентні; ієрархія загальнодержавної та локальних самоідентифікацій; відчуття сутнісної тотожності, спільного коріння тощо);

- образ минулого, теперішнього і майбутнього української державності (можливі і неможливі образи моєї держави);

- уявлення про цінність держави (чиї інтереси виражає, чиї захищає?);

- міфи і символи держави (національна спільнота, національна ідея, ідеологія, національні інтереси, імідж держави);

- ознаки національної належності (“свої” і “чужі”, що означає бути українцем?);

- самопроекцію в майбутнє (уявлення про себе і самореалізацію в державі, чи пов'язується власне майбутнє і майбутнє держави, особистісно значущі надії і страхи щодо власного майбутнього у своїй державі);

- потреби в цінностях свободи і правової держави, прагнення до регламентованості (уникнення неоднозначності смислів, потреба у строгих нормах і правилах, ясних і чітких відповідях на всі питання);

- ставлення до геополітичного позиціювання держави (зовнішньополітичні орієнтації, уявлення про національний суверенітет, національні інтереси, національну безпеку і стратегії розвитку);

- інтегрованість до політичної нації (знання історії, дотримання і збереження традицій, ставлення до сталості національних традицій, обізнаність щодо економічного, соціального, освітнього та інших напрямів державної політики).

Аналіз особливостей національної самоідентифікації здійснюватиметься за параметрами рефлексивності, ситуативності (надситуативності), механізмів ії конструювання (приєднання чи протиставлення, відповідно - позитивна чи негативна ідентичність) тощо.

Висновки:

1. Самоідентифікація відбувається у процесі комунікативної взаємодії, де особистість презентує власні смисли та оцінює пропозиції значущих Інших, формує власне ставлення і конструює образ “Я” динамічний, мінливий, нечітко окреслений.

2. Згідно із запропонованим визначенням та обраними емпіричними показниками громадянська самоідентифікація постає як процес 
усвідомлення суб'єктом власної потреби, готовності і спроможності визначати цілі і цінності, обирати міру і форми своєї активності задля забезпечення своїх інтересів та інтересів спільноти. Чим вищий рівень громадянської ідентифікації, тим більше вона відрефлексована, усвідомлена, раціональна.

3. Національно-державна самоідентифікація структурно, змістовно і функціонально складніша, ніж громадянська, до того ж її витоки більш ірраціональні. Переживання, що супроводжують самоідентифікацію з нацією-державою, окрім об'єктивних змінних (територіальні конфлікти і геополітичне та економічне становище держави, ії імідж у світі тощо), зумовлюються також міфами та історичними ремінісценціями, травматичними подіями і дитячими спогадами, родинними та місцевими традиціями, релігійними і побутовими звичаями тощо.

4. За результатами попереднього аналізу особливостей та змістових конструктів національної і громадянської самоідентифікацій 3 високою ймовірністю можна очікувати істотних відмінностей і в механізмах та чинниках їх розвитку.

\section{Лimepamypa}

1. Писаренко Н. В. Идентичность в аспекте коммуникации: теоретические подходы / Н. В. Писаренко // Вестник Томского государственного университета. - 2005. - № 286. - С. 118-122.

2. Кабрин В.И. Транскоммуникация и личностное развитие: психология коммуникативного развития человека как личности / В. И. Кабрин. Томск : Изд-во Том. ун-та, 1992. -255 с.

3. Колотаев В. А. Стадиальная модель развития идентичности (на примере киноискусства) / В.А.Колотаев, Е.В.У Улбина // Психология. Журнал Высшей школы экономики. - М., 2011. - Т. 8. - № 1. - С. 3-26.

4. Jenkins R. Social Identity / R. Jenkins. - London : Routledge, 2008. - 256 p.

5. Коростелина К. В. Исследование социальной идентичности на пути к примирению в Крыму / К. В. Коростелина. - Симферополь : Доля, 2003. $255 \mathrm{c}$.

\section{References}

1. Pisarenko, N. V. (2005). Identichnost $\mathrm{v}$ aspekte kommunikatsii: teoreticheskiye podkhody [Identity is in the aspect of communication: theoretical approaches]. Vestnik Tomskogo gosudarstvennogo universiteta [Bulletin of Tomsk State University], 286, 118-122 (rus).

2. Kabrin, V. I. (1992). Transkommunikatsiya i lichnostnoye razvitiye: psikhologiya kommunikativnogo razvitiya cheloveka kak lichnosti [Transcommunication and personality development: psychology of communicative development of man as a personality]. Tomsk: Tomsk State University Press (rus).

3. Kolotayev, V. A., Ulybina, Ye. V. (2011). Stadialnaya model razvitiya identichnosti (na primere kinoiskusstva) [Stadial model of identity development (on 
the example of cinematography)]. Psikhologiya. Zhurnal Vysshey shkoly ekonomiki [Psychology. Journal of Higher School of Economics], Vol. 8, no. 1, 3-26 (rus).

4. Jenkins, R. (2008). Social Identity. London: Routledge.

5. Korostelina, K. V. (2003). Issledovaniye sotsialnoy identichnosti na puti $k$ primireniyu $v$ Кrymu [Study of social identity on a way to reconciliation in Crimea]. Simferopol: Dolya Publ. (rus).

\section{Zhadan I. V. The empirical study of peculiarities of youth civic and national self-identification: basic concepts and indicators}

Following the constructivist and discourse approach self-identification is defined as a flexible discourse construct that constantly transforms in the process of social interaction and changes of psychological and social experiences of individual. With view to the role of communication in the development of identification processes, the author proposes self-identification classification on the basis of the method of sign and symbol interaction of an individual with others and the world. Certain method of using a sign as a means corresponds to one of the four identified levels of self-identification, which are a) identity marking; $b$ ) its symbolic comprehension; c) construction of categories and ideals which individuals identify them with; d) construction of conditions and rules of transforming the reality. The basic concepts are operationalized: national self-identification is defined as individual awareness of belonging to a political nation, which is social and cultural community with its experience of statehood, traditions, myths and symbols, common values and expectations of the future. Civic self-identification is defined as individual self-determination in the continuum of subjectity manifestations and identification with the community whose members are prepared and willing to defend their interests in the course of constructive social interaction. In this way the concepts are separated, the indicators of civic and national self-identification are identified and assumption about peculiarities of their manifestations on different levels is made as well.

Key words: civic and national self-identification, communication practices, method of using a sign.

(c) Жадан I. B. 
